Article

\title{
The Origin of Dissolved Sulphate in the Thermal Waters of Budapest Inferred from Stable $S$ and $O$ Isotopes
}

\author{
István Fórizs ${ }^{1, *}$, Viktória Rita Szabó ${ }^{2}$, József Deák ${ }^{3}$, Stanisław Hałas ${ }^{4,+}{ }^{\text {, Andrzej Pelc }}{ }^{4}$, \\ Andrzej Trembaczowski ${ }^{4}$ and Árpád Lorberer ${ }^{5,+}$ \\ 1 Institute for Geological and Geochemical Research, Research Centre for Astronomy and Earth Sciences, \\ Hungarian Academy of Sciences, H-1112 Budapest, Hungary \\ 2 Department of Physical and Applied Geology, Eötvös Loránd University, H-1053 Budapest, Hungary; \\ nyuszikae@gmail.com \\ 3 GWIS (Ground Water Isotope Studies) Ltd., H-8200 Veszprém, Hungary; deak47jozsef@gmail.com \\ 4 Institute of Physics, M. Curie-Skłodowska University, 20-031 Lublin, Poland; \\ Andrzej.Pelc@poczta.umcs.lublin.pl (A.P.); andrzej.trembaczowski@poczta.umcs.lublin.pl (A.T.) \\ 5 Retired Hydrogeologist, Budapest, Hungary \\ * Correspondence: forizs@geochem.hu \\ + Passed away.
}

Received: 16 August 2019; Accepted: 23 September 2019; Published: 8 October 2019

check for updates

\begin{abstract}
The thermal waters produced by wells and springs from the Buda Thermal Karst in Budapest and its surroundings are rich in dissolved sulphate. Radiocarbon ages indicate that waters of $\mathrm{T}>45^{\circ} \mathrm{C}$ were infiltrated during the Ice Age (more than 11 thousand years ago), on the higher elevations of the Buda-Pilis Hills, whereas waters of lower temperatures were infiltrated during the Holocene. For the origin of dissolved sulphate, two hypotheses can be set up: (1) the dissolved sulphate originates from the oxidation of the sulphide (pyrite) of Oligocene Clay Formation; (2) it is the dissolution product of the sulphate minerals (gypsum and anhydrite) of older carbonaceous rocks (limestone and dolomite). The isotopically stable sulphur composition of the dissolved sulphate in the thermal water $\left(\delta^{34} \mathrm{~S}=9.7 \%\right.$ o to $17.7 \%$ o) indicates its marine origin, so likely it dissolved from the older Permian evaporites.
\end{abstract}

Keywords: Buda Thermal Karst; thermal water; origin of dissolved sulphate; stable isotopes; geothermometry

\section{Introduction}

Budapest (Figure 1), known as city of spas, is very rich in thermal waters of various chemical compositions [1]. Thermal baths are an important treasure of the Hungarian capital city. The thermal waters are used mainly for balneological purposes; however, they are utilized as bottled water and for heating purposes as well. Most of these thermal waters are rich in dissolved sulphate [1,2]. In spite of the fact that the thermal waters of Budapest have been studied for more than one hundred years, nobody has examined in detail the origin of the dissolved sulphate, although some ideas were published about its origin [1-3]. One of the most reliable tools for the determination of the origin of sulphate is the application of environmentally stable isotopes; several papers demonstrated their usefulness (e.g., [4-8]). In our study, we would like to define the origin of the dissolved sulphate by means of the stable isotope measurements of dissolved sulphate $(\mathrm{S}$ and $\mathrm{O})$ and water $(\mathrm{O})$. 


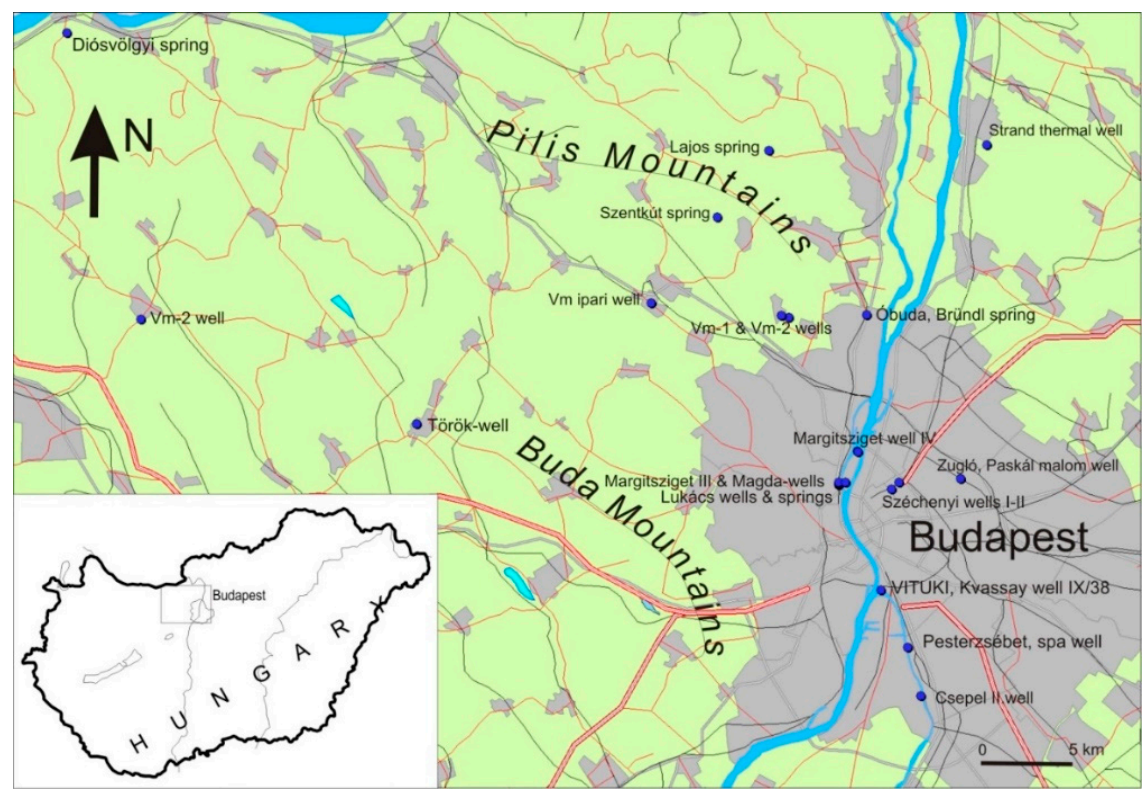

Figure 1. The location of the studied area in Hungary, and the sampling locations (blue dots) in Budapest and its surroundings.

\section{Hydrogeological Framework}

The study area is the main discharge area of the Transdanubian Range. Both shallow (cold) and deep (warm) karstic flow systems end in the study area (Figure 2), and mixing between these two flow systems occurs at several places. At the Southern and Eastern foots of the Buda and Pilis Mountains (Figure 1), near the base level at the River Danube, there are many thermal $\left(>30^{\circ} \mathrm{C}\right)$ and lukewarm (from $15{ }^{\circ} \mathrm{C}$ to $30^{\circ} \mathrm{C}$ ) springs, which came from karstified Triassic and Eocene carbonaceous rocks [2]. The warmest component of water flow is in the basement of the Pest side (Figure 2), where karstified rocks are covered by thick sediment. The main mass of Buda and Pilis Mountains consist of well karstified Triassic platform carbonates. The reservoir of thermal waters of Budapest is mainly made of the Triassic karstified and fissured carbonaceous bedrock (limestone and dolomite). This Triassic bedrock is covered somewhere by Eocene carbonaceous rocks (Nummulite bearing limestone) [3]. The Upper Triassic bedrock is in hydraulic connection with the covering Upper Eocene formations in northern and southeastern Budapest [2]. The recharge area of Buda Thermalkarst is not defined exactly, but the discharge area can be delineated more exactly, because of its connection to tectonic lines. This concentrated discharge area is the Buda Spring-line at the right bank of the River Danube.

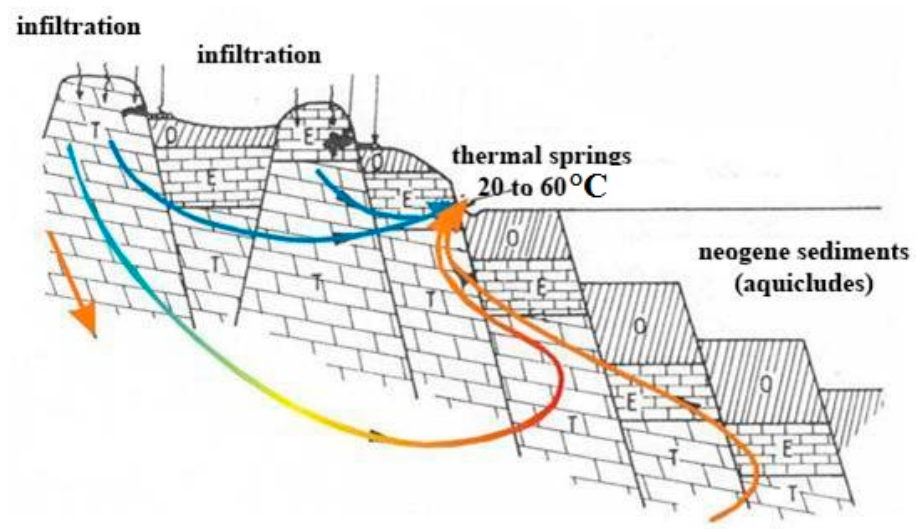

Figure 2. Conceptual flow model of the Buda Thermal Karst system from Vendel-Kisházi (1964) [9]. Abbreviations: T-Triassic dolomite; E-Eocene limestone and Eocene-Oligocene marl; $\mathrm{O}$ —Oligocene clay. 
The springs emerge mainly along a north-south oriented path at the Buda side; some of them are in the bed of River Danube. The springs can be divided into two groups based on their chemistry and temperature: (1) the southern group of higher temperature and higher TDS (total dissolved solids), and (2) the northern group of lower temperature and lower TDS [2].

The Upper Triassic formations of the main thermal aquifer is deposited over older South-West Lower Triassic and Upper Permian rocks which contain evaporites (gypsum and anhydrite). These formations are known only from the Southwestern flank of the Budapest area, extending farther towards the Southwest. These limestones, marls and sandstones have low transmissivity and they are barely karstified, rather they are fissured crack water horizons. The Budapest flow system can probably reach only the very end of the known evaporite sediments. However, in the SW border of Budapest, at the Alcsútdoboz-Biatorbágy-Törökbálint-Budaörs-Budatétény line, they can probably communicate through a big horizontal surface with the more karstified Middle and Upper Triassic dolomites and limestones. The higher sulphate content of thermal water in South Budapest can be explained with that counterclockwise water flow system which contacts the Permian-Triassic evaporitic rocks (Figure 3). A more detailed description of the hydrogeological setting was published in 2017 by Mádl-Szőnyi et al. [10].

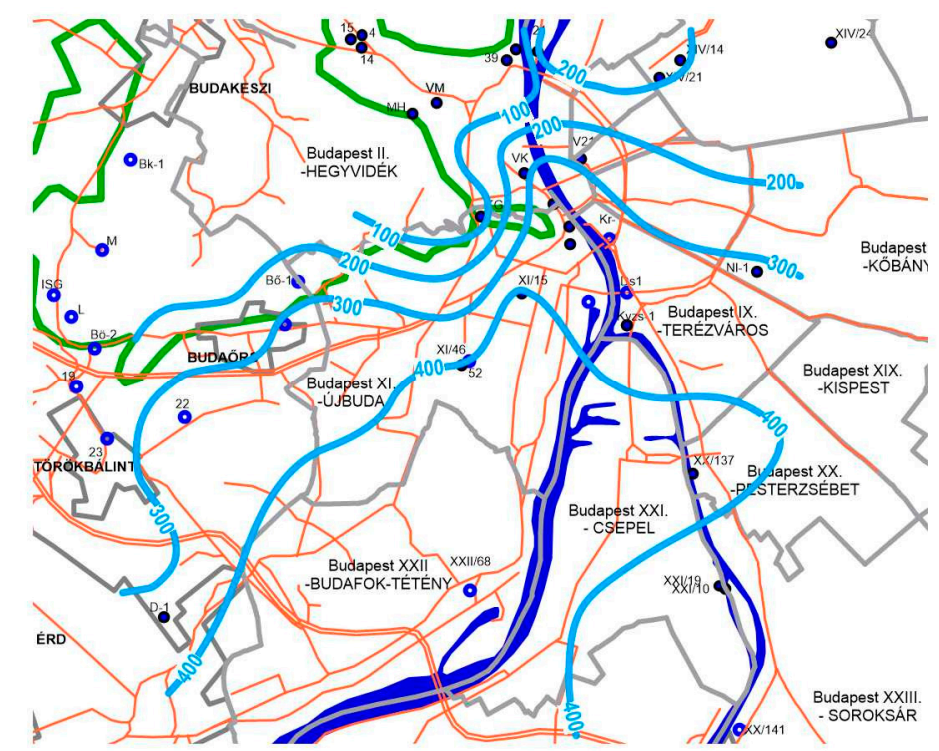

Figure 3. The distribution of the dissolved sulphate $(\mathrm{mg} / \mathrm{L})$ in the thermal waters of Budapest. Isolines (light blue) are interpolated from the point data by manual interpretation based on linear estimation (Á. Lorberer co-author). Key: blue dots-measured karst wells; blue circles—other karst wells having $\mathrm{SO}_{4}$-measurements; green lines-border between the unconfined mountainous part and the confined thermal part of the aquifer; grey lines—district and city borders; orange lines—main roads.

\section{Samples and Analytical Methods}

Twelve thermal water samples $\left(>30^{\circ} \mathrm{C}\right.$ ), four lukewarm water samples (between $15^{\circ} \mathrm{C}$ and $30^{\circ} \mathrm{C}$ ) and eight cold-water samples $\left(<15^{\circ} \mathrm{C}\right)$ were taken from springs and wells in Budapest and its surroundings (Figure 1) The dissolved sulphate was precipitated from 1-3 $\mathrm{L}$ of water on the spot as $\mathrm{BaSO}_{4}$, by applying $\mathrm{BaCl}_{2}$. Beside the $\mathrm{BaSO}_{4}$, some $\mathrm{BaCO}_{3}$ was precipitated as well. The latter was removed by hydrochloric acid in the Institute for Geological and Geochemical Research, Research Centre for Astronomy and Earth Sciences, Hungarian Academy of Sciences; meanwhile, the $\mathrm{pH}$ was strictly kept above 3, avoiding any oxygen isotopic exchange between water and sulphate. The pure $\mathrm{BaSO}_{4}$ samples were rinsed 5-8 times by deionized water, and then dried in oven at $60{ }^{\circ} \mathrm{C}$. These samples of dry $\mathrm{BaSO}_{4}$ powder were mailed to the Mass Spectrometry Laboratory of Institute of Physics of Maria Curie-Skłodowska University (Lublin, Poland) for the determination of their $\delta^{34} S$ and $\delta^{18} \mathrm{O}$ values. The oxygen isotopic composition 
of the water samples $(0.6 \mathrm{dL})$ was determined in the Institute for Geological and Geochemical Research, Research Centre for Astronomy and Earth Sciences, Hungarian Academy of Sciences (Budapest, Hungary). The isotopic compositions are given in the traditional delta notation as $\delta=\left(R_{s} / R_{s t}-1\right) \times 1000 \%$, where $R_{s}$ and $\mathrm{R}_{\mathrm{st}}$ are the ${ }^{18} \mathrm{O} /{ }^{16} \mathrm{O}$ or ${ }^{34} \mathrm{~S} /{ }^{32} \mathrm{~S}$ isotopic ratios in the sample and standards, respectively. International standards: VSMOW (Vienna Standard Mean Ocean Water) for oxygen and CDT (Canon Diablo Troilite) for sulphur.

Both the sampling, and chemical analyses of the samples, were performed in the Laboratory of the Spas and Thermal Waters of Budapest Ltd, according to the related ISO standards.

\section{Results}

The temperature of the studied water samples varies from $8.9^{\circ} \mathrm{C}$ to $76.8^{\circ} \mathrm{C}$. The lukewarm and cold-water samples were taken for the sake of comparison. The stable oxygen isotopic compositions of the waters $\left(\delta^{18} \mathrm{O}\right.$, Table 1 ) were in the range of $-12.50 \%$ o to $-9.38 \%$ o against VSMOW (mean value of all samples is $-10.82 \%$ o). The mean value of the thermal samples is $-11.68 \%$, which is a more negative value than that of lukewarm and cold-waters. The stable sulphur isotopic composition of the dissolved sulphate $\left(\delta^{34}\right.$ S, Table 1 ) was from $-5.66 \%$ o to $17.72 \%$ versus VCDT (mean value of all samples is $7.08 \%$ o). The $\delta^{34} \mathrm{~S}$ values of sulphate varied from $9.68 \%$ o to $17.72 \%$. Their mean value is $13.22 \%$, which is more positive than that of colder waters. The stable oxygen isotopic compositions of the dissolved sulphate $\left(\delta^{18} \mathrm{O}\right.$, Table 1$)$ were from $0.68 \%$ o to $6.39 \%$ o (mean value of all samples is $4.18 \%$ ). The mean value of the thermal samples is $5.13 \%$, which is more positive than that of colder waters.

Table 1. Water temperature $\left[{ }^{\circ} \mathrm{C}\right], \delta^{34} \mathrm{~S}$ and $\delta^{18} \mathrm{O}$ values $[\%$ o of dissolved sulphate and water, grouped into temperature ranges.

\begin{tabular}{|c|c|c|c|c|}
\hline Well/Spring & $\begin{array}{l}\delta^{34} S[\% o] \\
\text { Sulphate }\end{array}$ & $\begin{array}{c}\delta^{18} \mathrm{O}[\% \text { o] } \\
\text { Water }\end{array}$ & $\begin{array}{l}\delta^{18} \mathrm{O}[\% o] \\
\text { Sulphate }\end{array}$ & $\begin{array}{c}\mathrm{T}_{\text {water }} \\
{\left[{ }^{\circ} \mathrm{C}\right]}\end{array}$ \\
\hline \multicolumn{5}{|c|}{ Thermal Waters $\left(>30^{\circ} \mathrm{C}\right)$} \\
\hline Csepel II well (Budapest) & 15.61 & -12.01 & 5.45 & 45.2 \\
\hline Széchenyi II well (Budapest) & 17.18 & -12.46 & 4.91 & 76.8 \\
\hline Széchenyi I well (Budapest) & 17.72 & -12.50 & 5.05 & 73.0 \\
\hline Lukács IV well (Budapest) & 11.63 & -11.59 & 4.22 & 52.5 \\
\hline Lukács V well (Budapest) & 10.28 & -11.36 & 5.18 & 50.9 \\
\hline VITUKI, Kvassay-well IX/38 (Budapest) & 11.65 & -11.53 & 5.27 & 46.2 \\
\hline Pesterzsébet, spa well (Budapest) & 11.32 & -11.60 & 5.21 & 41.8 \\
\hline Zugló, Paskál malom well (Budapest) & 13.35 & -11.75 & 6.39 & 67.7 \\
\hline Margitsziget, Magda-well (Budapest) & 16.12 & -11.88 & 5.36 & 69.0 \\
\hline Margitsziget, IV well (Budapest) & 9.68 & -10.95 & & 38.1 \\
\hline Margitsziget, III well (Budapest) & 10.19 & -10.99 & 4.47 & 37.8 \\
\hline Strand thermal well (Göd) & 14.01 & -11.87 & 4.94 & 50.4 \\
\hline \multicolumn{5}{|c|}{ Lukewarm Waters $\left(15-30^{\circ} \mathrm{C}\right)$} \\
\hline Lukács, Boltív spring (Malom Lake) (Budapest) & -4.91 & -10.48 & 2.64 & 22.0 \\
\hline Lukács, Római spring (Budapest) & -5.66 & -10.30 & 2.87 & 20.8 \\
\hline Lukács, Török spring (Budapest) & -3.60 & -10.58 & & 23.9 \\
\hline Óbuda, Bründl spring (Budapest) & -2.47 & -10.24 & & 18.5 \\
\hline
\end{tabular}


Table 1. Cont.

\begin{tabular}{|c|c|c|c|c|}
\hline Well/Spring & $\begin{array}{l}\delta^{34} S[\% \text { [ ] } \\
\text { Sulphate }\end{array}$ & $\begin{array}{c}\delta^{18} \mathrm{O}[\% \text { o }] \\
\text { Water }\end{array}$ & $\begin{array}{l}\delta^{18} \mathrm{O}[\% \text { o] } \\
\text { Sulphate }\end{array}$ & $\begin{array}{c}\mathrm{T}_{\text {water }} \\
{\left[{ }^{\circ} \mathrm{C}\right]}\end{array}$ \\
\hline \multicolumn{5}{|c|}{ Cold Waters $\left(<15^{\circ} \mathrm{C}\right)$} \\
\hline Vízmúvek-1 (3. works) well (Pilisborosjenő) & -0.22 & -9.38 & 4.12 & 14.4 \\
\hline Vízmúvek-2 (4. works) well (Pilisborosjenő) & -1.15 & -9.96 & & 13.3 \\
\hline Vízmúvek, Ipari well (Pilisszentiván) & 7.51 & -9.99 & 3.87 & 11.0 \\
\hline Szentkút spring (Csobánka) & 1.32 & -9.81 & & 9.4 \\
\hline Török-well (Zsámbék) & 7.04 & -10.24 & 2.59 & 12.5 \\
\hline Lajos spring (Szentendre) & 8.08 & -10.67 & 2.10 & 9.4 \\
\hline Diósvölgyi spring (Süttő) & 8.32 & -9.70 & & 12.4 \\
\hline Vízmúvek 2. well (Tarján) & 1.71 & -10.10 & & 12.1 \\
\hline Szentkút spring (Csobánka) & 2.37 & -9.74 & 0.68 & 8.9 \\
\hline
\end{tabular}

\section{Discussion}

The thermal wells and springs in Budapest and its surroundings are rich in dissolved sulphate. For the origin of this sulphate two hypotheses exist: (1) The dissolved sulphate originates from the oxidation of the sulphide (pyrite) of the Oligocene Kiscelli and Tard Clay Formations. This formation contains significant amounts of organic matter and sulphide; the latter is mostly in pyrite form. This pyrite can be oxidized where thermal water makes a contact with the clay. (2) The dissolved sulphate is a dissolution product of the sulphate minerals (gypsum, anhydrite) found in the Southwestern extension of the main Triassic karst limestone and dolomite aquifer [2].

\subsection{Checking the Two Hypotheses Using Sulphate's Sulphur Isotopes}

\subsubsection{The Oxidation of Sulphide}

Vetô et al. [11] published the $\delta^{34} S$ values of total sulphur in the Tard Clay Formation (Alcsútdoboz-3 borehole). The mean value of the total sulphur of the clay was $2.6 \%$. Because sulphur in the clay is nearly $100 \%$ pyrite, the value $\delta^{34} \mathrm{~S}=2.6 \%$ o can be regarded as that of pyrite. When pyrite is oxidized in abiogenic processes, the $\delta^{34} \mathrm{~S}$ value of the sulphate formed is close to the value of original pyrite. When pyrite is oxidized in biogenic processes, the $\delta^{34} S$ value of the sulphate formed is lower than that of pyrite. Since the mean $\delta^{34} S$ value of the sulphate dissolved in the thermal waters studied is much more positive (average $13.6 \%$ o) than that of the pyrite in the Tard Clay Formation, $(2.6 \%$ o), the first hypothesis that the dissolved sulphate originates from the oxidation of the sulphide (pyrite) in the Tard Clay Formation, is unlikely.

\subsubsection{The Dissolution of Sulphate}

Hámor [12], in his study about sedimentary sulphates, measured sulphur's stable isotopic compositions mainly in Upper Permian and Lower Triassic evaporites. In these two groups, the isotopic compositions of the sulphur are significantly different. The $\delta^{34} S$ values of the Permian samples were from $9.51 \%$ o to $20.93 \%$ o (mean value is $12.78 \%$; [13]). These Permian samples had been taken from several boreholes in Hungary (Bódvaszilas-1, Bódvarákó-4, Dinnyés-3, Hídvégardó-3, Jósvafó-2, Nagybátony-324, Nagyvisnyó-4, Nagyvisnyó-18, Perkupa-mine, Recsk-136 and Tornakápolna-3). The $\delta^{34} S$ values measured for the samples mentioned roughly correspond with world values of Permian marine sulphates [14-16]. The $\delta^{34} \mathrm{~S}$ values of the Triassic samples were from $15.98 \%$ o to $33.01 \%$, with wide dispersion (mean $\delta^{34} \mathrm{~S}$ value is $24.28 \%$ ), and are in good agreement with the global values [16]. These Triassic samples had been taken from several boreholes in Hungary (Alcsútdoboz-2, Alsószalmavár-1, Bakonyszúcs-1 and 3, Barcs-West-6, 8, Báta-3, Cún-1, Diósviszló-3, Forráskút-4, 
Iszkaszentgyörgy-4, Kiskunhalas-North-3, Kiskunhalas-South-5, Máriakéménd-3, Nagykozár-2, Ortaháza-West-1, Öttömös-2, Petend-1, Somberek-1, Tét-2, Turony-1, Vajta-3 and XIV.).

The results obtained prove our second hypothesis, that the dissolved sulphate is a dissolution product of evaporites, because in our study, the $\delta^{34} \mathrm{~S}$ values of the thermal waters were between $9 \%$ and $18 \%$ o (average is $13.22 \%$ ), which practically overlaps with the range of the above Permian evaporites; the latter is within the range of "Devonian to Lower Triassic" in Figure 4. There is a small overlap between the range of the measured $\delta^{34} S$ values of thermal waters $(9-18 \%$ ) and the above Triassic suphates (16-33\%o), so some of the dissolved sulphate could originate from Triassic sources, but the amount must be inferior.

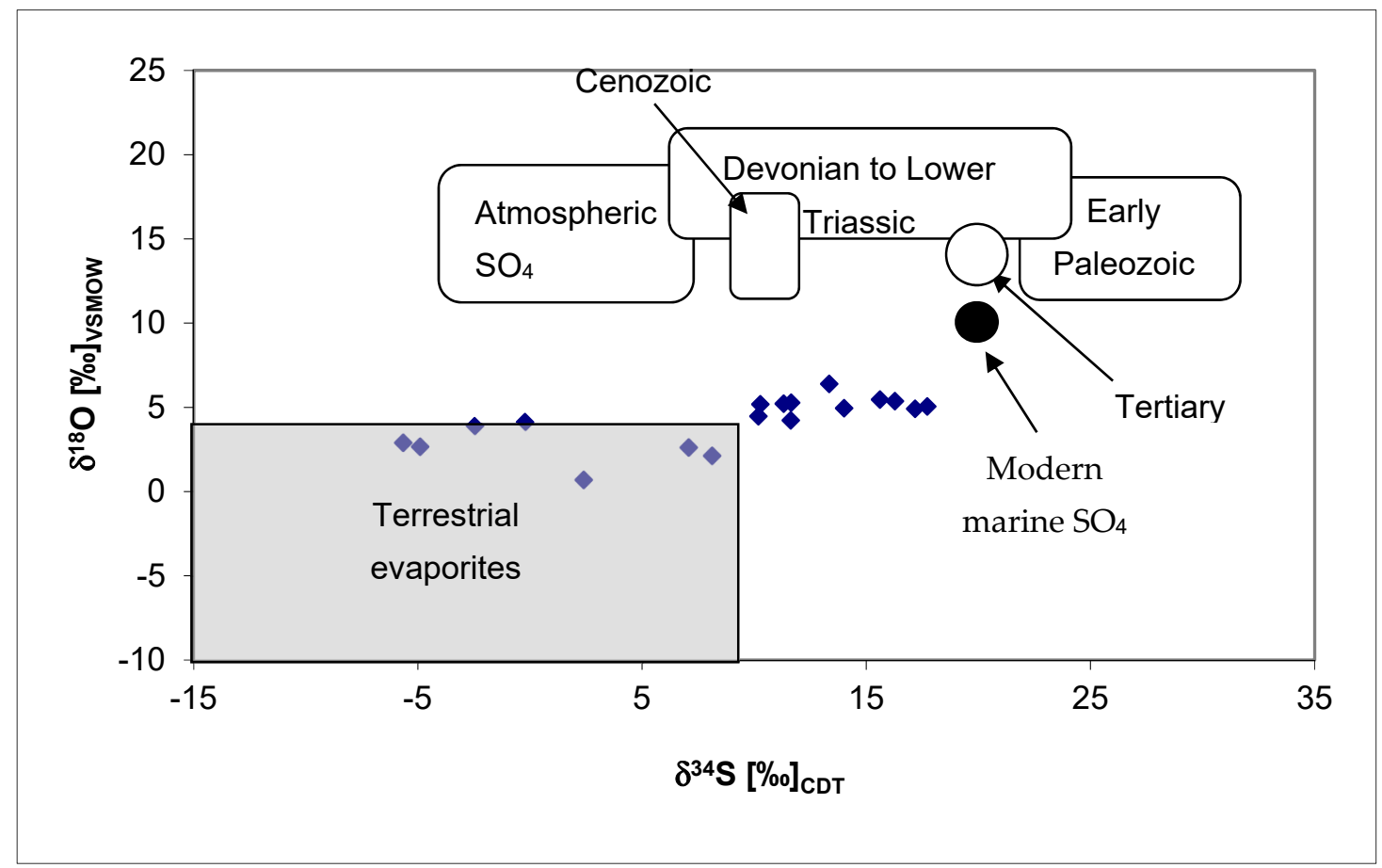

Figure 4. The isotopic composition of the dissolved sulphate in the thermal waters of Budapest and its surroundings on the $\delta^{34} \mathrm{~S}-\delta^{18} \mathrm{O}$ diagram in comparison with terrestrial, marine and atmospheric sulphates [17].

\subsection{An Evaluation of the Chemical Data}

The water chemistry may provide information about the sources of chemical species dissolved in the water (e.g., [18]). Here we provide a simple evaluation of chemical data just for checking whether the conclusion made on the basis of stable isotope data above is supported by the chemical data or not. In the previous chapter, we concluded that the dissolved sulphate in the thermal waters originates from the dissolution of sulphate minerals. Figure 5a indicates that there is a significant amount of surplus calcium compared to the congruent dissolution of sulphate (all the points are over the 1:1 dissolution line), necessarily so, because carbonate minerals have dissolved as well increasing the amount of Ca. But, if we compare the Ca with $\mathrm{SO}_{4}+\mathrm{HCO}_{3}$ (Figure 5b) it is obvious that there is a shortage in $\mathrm{Ca}$, because not only calcite dissolved, but dolomite as well. Regarding the model of dissolution of gypsum (and/or anhydrite), calcite and dolomite as sources for the $\mathrm{Ca}, \mathrm{Mg}, \mathrm{SO}_{4}$ and $\mathrm{HCO}_{3}$ species in the water, Figure 5 c gives a support for it, showing a fairly good correlation between $\mathrm{Ca}+\mathrm{Mg}$ and SO $4+\mathrm{HCO}_{3}$. We may suppose that dissolution of halite is the source of chloride. Although the $\mathrm{Na}-\mathrm{Cl}$ correlation is fairly good (Figure 5d) in many cases there is some surplus Na over the 1:1 line. This can be explained as the result of the $\mathrm{Ca} \leftrightarrow(\mathrm{Na}, \mathrm{K})$ cation exchange between water and clay minerals. Clay releases $\mathrm{Na}$ or $\mathrm{K}$ and receives $\mathrm{Ca}$ ([19] chapter 4). It means that the $\mathrm{Ca}+\mathrm{Mg}$ should be corrected with this surplus $\mathrm{Na}+\mathrm{K}$, which is over the dissolution of halite $(\mathrm{Na}+\mathrm{K}-\mathrm{Cl})$. Figure 5 e shows the corrected 
diagram, where the correlation is a little bit better than in the Figure 5c. Because not all the points are on the 1:1 line, we can infer that additional processes played roles, although minor ones. If we group the waters according to temperature into three intervals (Table 1), then there is no clear separation between the groups (Figure 5f), which can be the result of the mixing of cold and warm waters.

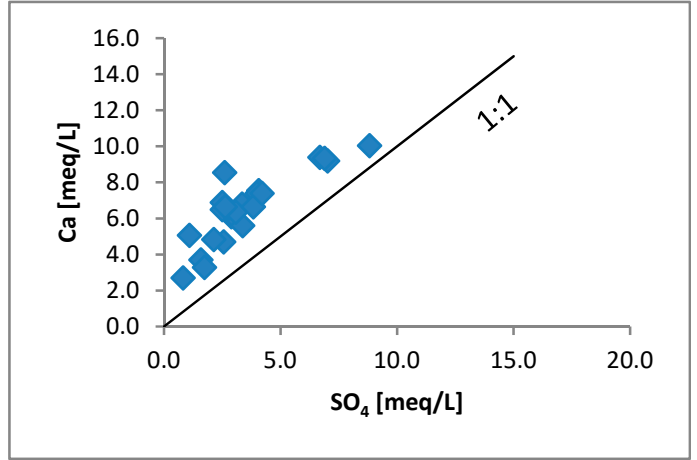

(a)

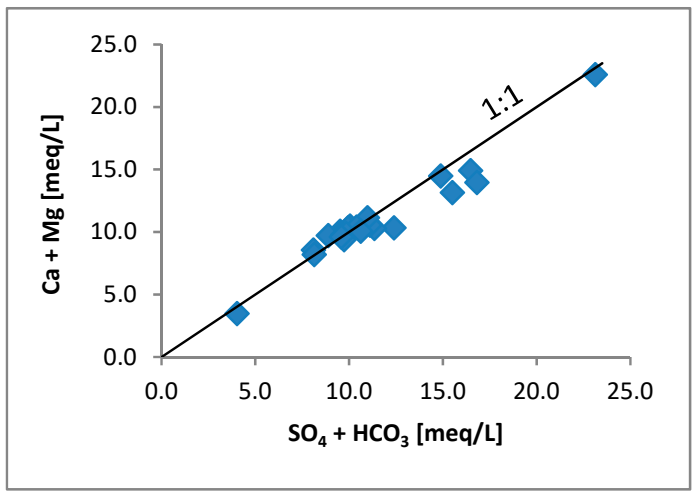

(c)

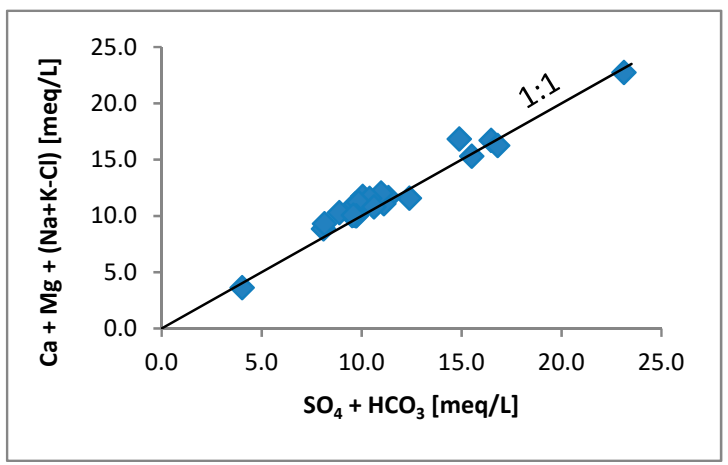

(e)

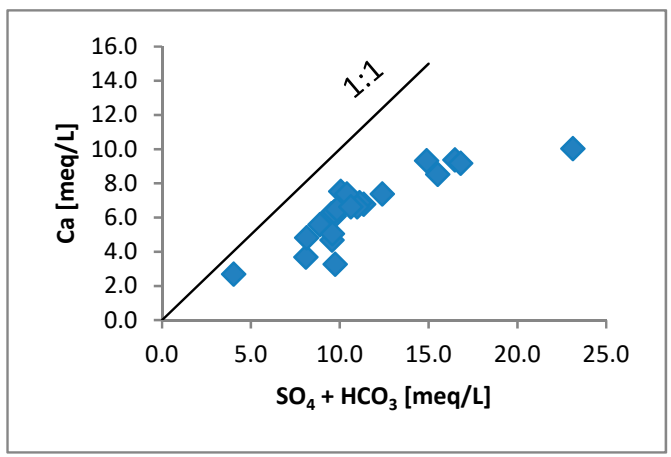

(b)

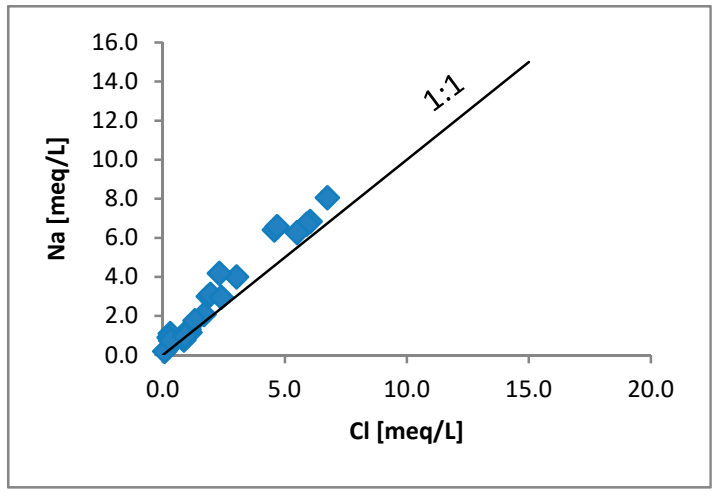

(d)

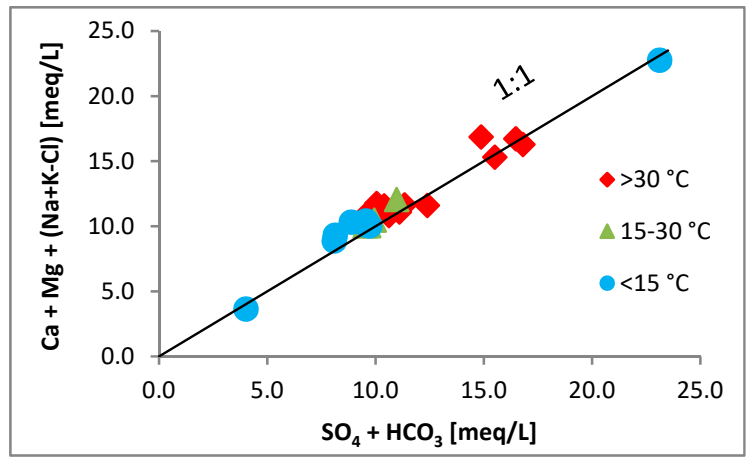

(f)

Figure 5. Graphs showing the relationship between the chemical components of the studied waters. Every component is in milliequivalent/litre (meq/L). The 1:1 line indicates the congruent dissolution(s) involved. (a) Ca versus $\mathrm{SO}_{4}$; (b) Ca versus $\mathrm{SO}_{4}+\mathrm{HCO}_{3}$; (c) $\mathrm{Ca}+\mathrm{Mg}$ versus $\mathrm{SO}_{4}+\mathrm{HCO}_{3}$; (d) $\mathrm{Na}$ versus Cl; (e) and (f) $\mathrm{Ca}+\mathrm{Mg}+(\mathrm{Na}+\mathrm{K}-\mathrm{Cl})$ versus $\mathrm{SO}_{4}+\mathrm{HCO}_{3}$.

As we can see, the conclusion drawn by the stable isotope data of dissolved sulphate is supported by the chemical data. 


\subsection{Water Oxygen Isotopic Composition}

The oxygen isotopic composition of the infiltrated water in Hungary is very close to that of the local precipitation [20]. Since the multi-annual stable isotopic characteristics of precipitation depends on the climate, the $\delta^{18} \mathrm{O}$ value of the infiltrated water reflects the climate in the time of infiltration. The $\delta^{18} \mathrm{O}$ values of the studied water samples (Table 1$)$ show that the thermal waters $\left(\delta^{18} \mathrm{O}\right.$ from $-12.50 \%$ o to $-10.95 \%$ o) were infiltrated under a cooler climate during the Ice Age [21], while the cold-waters $\left(\delta^{18} \mathrm{O}\right.$ from $-10.67 \%$ o to $-9.38 \%$ o) were infiltrated during the Holocene [21]. The lukewarm waters $\left(\delta^{18} \mathrm{O}\right.$ is from $-10.58 \%$ o to $-10.24 \%$ o) are mixture of thermal and cold-waters. This is in harmony with $\delta^{34} \mathrm{~S}$ values.

\subsection{Oxygen Isotope, Bisulphate-Water Geothermometer}

In our thermal water samples, $\delta^{18} \mathrm{O}$ values of the dissolved sulphate (bisulphate) were lower by $5-10 \%$ o than Permian and Triassic marine sulphate values (12-18\%o, Figure 3) $[15,18,22]$. There is an isotope exchange between the bisulphate and water which is rather fast over $200{ }^{\circ} \mathrm{C}$ [23] and significantly slower in lower temperatures; however, both $\mathrm{pH}$ and chemistry play important roles in determining the exchange rate. McKenzie and Truesdell [24] gave a formula for calculating the half time of oxygen exchange between bisulphate and water at different $\mathrm{pHs}$ and temperatures. We have calculated the time needed for $99.9 \%$ exchange of oxygen in the bisulphate-water system at $\mathrm{pH} 7$ for different temperatures; see Table 2. Because the formula was given for $\mathrm{pHs} 3.8,7$ and 9, we made the calculations for $\mathrm{pH} 7$, because it is the closest value to the $\mathrm{pH}$ we measured in the thermal waters studied (Table 3). Although the $99.9 \%$ exchange does not mean isotopic equilibrium, it can be regarded as a good approximation of the equilibrium.

Table 2. Time needed for $99.9 \%$ exchange of $\mathrm{O}$ in the bisulphate-water system calculated at $\mathrm{pH} 7 \mathrm{using}$ the formula of McKentzie and Truesdell [24]. a = year.

\begin{tabular}{cccccccc}
\hline Temperature $\left[{ }^{\circ} \mathbf{C}\right]$ & $30{ }^{\circ} \mathbf{C}$ & $\mathbf{4 0}{ }^{\circ} \mathbf{C}$ & $\mathbf{5 0}{ }^{\circ} \mathbf{C}$ & $\mathbf{6 0}{ }^{\circ} \mathbf{C}$ & $\mathbf{7 0}{ }^{\circ} \mathbf{C}$ & $\mathbf{8 0}{ }^{\circ} \mathbf{C}$ & $\mathbf{9 0}^{\circ} \mathbf{C}$ \\
\hline Time needed for $99.9 \%$ exchange $(10 \times$ half time) $[\mathrm{a}]$ & 18,445 & 9962 & 5589 & 3246 & 1946 & 1201 & 761 \\
\hline
\end{tabular}

Table 3. The temperatures measured $\left(\mathrm{T}_{\text {water }}\right)$, thermometer temperatures $\left(\mathrm{T}_{\text {water }}\right.$ calculated), oxygen isotopic composition of dissolved sulphate, $\mathrm{pH}$ and ${ }^{13} \mathrm{C}$-corrected radiocarbon ages of thermal waters.

\begin{tabular}{cccccc}
\hline Thermal Wells & $\begin{array}{c}\mathbf{T}_{\text {water }} \\
{\left[{ }^{\circ} \mathbf{C}\right]}\end{array}$ & $\begin{array}{c}\mathbf{T}_{\text {water }}\left[{ }^{\circ} \mathbf{C}\right] \\
\text { Calculated }\end{array}$ & $\begin{array}{c}\boldsymbol{\delta}^{\mathbf{1 8}} \mathbf{O}[\mathbf{\% o}] \\
\text { Sulphate }\end{array}$ & $\mathbf{p H}$ & $\begin{array}{c}\mathbf{1 4}^{\mathbf{1 4}} \text { age }\left({ }^{\mathbf{1 3}} \mathbf{C} \text {-corr.) }\right. \\
{[\mathbf{1 0} \times \mathbf{a}]}\end{array}$ \\
\hline Csepel II well (Budapest) & 45.2 & 75.1 & 5.45 & 6.6 & 23.5 \\
\hline Széchenyi II well (Budapest) & 76.8 & 75.7 & 4.91 & 6.4 & 18.9 \\
\hline Széchenyi I well (Budapest) & 73.0 & 74.4 & 5.05 & 6.4 & 19.0 \\
\hline Lukács IV well (Budapest) & 52.5 & 87.3 & 4.22 & 6.9 & 3.0 \\
\hline Lukács V well (Budapest) & 50.9 & 81.8 & 5.18 & 6.9 & 4.7 \\
\hline VITUKI, Kvassay-well IX/38 (Budapest) & 46.2 & 79.9 & 5.27 & 6.8 & 14.6 \\
\hline Pesterzsébet, spa well (Budapest) & 41.8 & 79.8 & 5.21 & 6.7 & 15.8 \\
\hline Zugló, Paskál malom well (Budapest) & 67.7 & 70.5 & 6.39 & 6.5 & 15.2 \\
\hline Margitsziget, Magda-well (Budapest) & 69.0 & 76.6 & 5.36 & 6.7 & 15.5 \\
\hline Margitsziget, IV well (Budapest) & 38.1 & & & 6.9 & 4.9 \\
\hline Margitsziget, III well (Budapest) & 37.8 & 90.1 & 4.47 & 6.8 & 7.0 \\
\hline Strand thermal well (Göd) & 50.4 & 79.7 & 4.94 & 6.4 & 17.1 \\
\hline
\end{tabular}

Comparing the data in Table 2 with the water temperatures measured and the calculated radiocarbon ages in Table 3, we can see that the oxygen isotopic equilibrium in the bisulphate-water system has supposedly been attained in the majority of the waters except in four wells: Lukács IV and 
$\mathrm{V}$, and Margitsziget III and IV wells, which are younger than nine-thousand years (ka), while the time needed for equilibrium is more than $9 \mathrm{ka}$ at the outflow temperature.

Several authors dealt with the temperature dependence of oxygen isotope fractionation factor in the bisulphate-water system [23,25-28]. We tried the equations of Lloyd [25], Mizutani and Rafter [26] and Kusakabe and Robinson [23], and found that Equation (1), published by Kusakabe and Robinson [23], gave temperatures closest to the measured ones. They were the only authors who applied a correction for ion hydration effects, which is significant, and this can be a reason that their formula gave the closest temperatures.

$$
10^{3} \ln \alpha_{\left(\mathrm{BaSO}_{4}-\mathrm{H}_{2} \mathrm{O}\right)}=3.01\left(10^{6} / \mathrm{T}^{2}\right)-7.3 \pm 0.1
$$

Although Kusakabe and Robinson determined the $\mathrm{O}$ isotope fractionation factor of the $\mathrm{BaSO}_{4}-\mathrm{H}_{2} \mathrm{O}$ system, it can be regarded as the fractionation factor of the $\mathrm{HSO}_{4}-\mathrm{H}_{2} \mathrm{O}$ system, because the isotope fractionation between the solid $\mathrm{BaSO} 4$ and the dissolved $\mathrm{HSO} 4$ is negligible (e.g., [18] (p. 141)) both for $\mathrm{S}$ and $\mathrm{O}$.

Comparing the measured outflow temperature with the temperature determined by the bisulphate-water geothermometer at waters of radiocarbon age $>9 \mathrm{ka}$, we could see that thermometer $\mathrm{T}$ in three wells was equal to the measured T within $\pm 2{ }^{\circ} \mathrm{C}$ (Széchenyi I and II wells; Zugló and Paskál malom wells); and in five wells it was significantly higher (Csepel II. well; VITUKI, Kvassay-well IX/38; Pesterzsébet, spa well; Margitsziget, Magda-well; Göd, strand thermal well) (Table 3). When the measured and the calculated geothermometer temperatures were ca. equal, then we may conclude that isotopic equilibrium was attained and neither mixing nor cooling took place; i.e. the water came from one flow path and its temperature was never significantly higher than the present one. Those wells are spatially close to each other and get their water from the ascending structures in faults close to each other. In the case that the calculated geothermometer $\mathrm{T}$ is significantly higher than the outflow temperature, theoretically, there are two explanations for this phenomenon. (1) Water comes from deep aquifers, where the temperature is high, and cools down during the ascension. The geothermometer gives the temperature of the deep aquifer, because the time of ascension is too short for re-equilibration. (2) The other explanation can be the mixing of small amount of cool water of low bisulphate content to the ascending hot water. In this case, the vast majority of the bisulphate originates from the hot component, but a small portion may come from the cool component, slightly modifying the $\delta^{18} \mathrm{O}_{\mathrm{HSO}}$. It is true for the $\delta^{18} \mathrm{O}_{\mathrm{H} 2 \mathrm{O}}$ as well; it can be slightly modified by the cool component. The $\delta^{18} \mathrm{O}$ values of cool waters were higher than of the hot waters (Table 1), while the $\delta^{18} \mathrm{O}$ values of bisulphate in cool waters were lower than in the hot waters (Table 1). Both an increase in $\delta^{18} \mathrm{O}_{\mathrm{H} 2 \mathrm{O}}$ and a decrease in $\delta^{18} \mathrm{O}_{\mathrm{HSO} 4}$ increase the geothermometer temperature calculated. At the same time, the effect of mixing of a small amount of young water with old water is very remarkable on the calculated radiocarbon age, resulting in a significantly younger age. (It is because a small increase in the ${ }^{14} \mathrm{C}$ content results a great decrease in the radiocarbon age; the correlation between the age and ${ }^{14} \mathrm{C}$ content is exponential.) Keeping in mind the above statements and having a look at the data in Table 3, we can see the following: in the case when the geothermometer $\mathrm{T}$ and the outflow $\mathrm{T}$ are close to each other, the $\mathrm{T}$ is in the range of $70-76^{\circ} \mathrm{C}$. The same geothermometer T characterizes some other wells: Csepel II well and Margitsziget Magda-well. Both are rather old (23.5 and $15.5 \mathrm{ka}$ ), and the outflow Ts are significantly lower than the geothermometer Ts, although for the latter, the difference is smaller. At these two wells, we may interpret the data such that the ascending water cooled down without mixing; therefore, the geothermometer gave the highest temperatures these waters had along their flow path.

There are three wells where the geothermometer $\mathrm{T}$ is just a little bit higher $\left(79.7-79.9^{\circ} \mathrm{C}\right)$ than the previously mentioned ones. These are: the VITUKI, Kvassay-well IX/38; the Pesterzsébet, spa well; the strand thermal well (Göd). All these waters are rather old waters, 14.6, 15.8 and $17.1 \mathrm{ka} \mathrm{cal} .{ }^{14} \mathrm{C}$. It may be that a small amount of cool water mixes into the hot water, but according to the data it was insignificant, if it took place. In all the other cases, the geothermometer $\mathrm{T}$ is over $80^{\circ} \mathrm{C}$, and at the same time the radiocarbon age is under 7 ka: Lukács IV-V wells; Margitsziget III well. Although the 
geothermometer temperatures can be realistic, because at Tura (in the most eastern part of the Buda Thermal Karst) ca. $100^{\circ} \mathrm{C}$ was measured in a lately drilled well, the parallel increase in geothermometer $\mathrm{T}$ and significant decrease in the radiocarbon age clearly indicates the mixing of young and cool water to the old and hot water.

\subsection{The Possible Effect of $\mathrm{S}^{2-}$ Content on the $\delta^{18} \mathrm{O}_{\mathrm{HSO}}$}

In six thermal water samples, we detected a little amount of $\mathrm{S}^{2-}$ (from $0.2 \mathrm{mg} / \mathrm{L}$ to $0.98 \mathrm{mg} / \mathrm{L}$, Table 4), which may indicate bacterial reduction of sulphate, which involves isotope fractionation. However, the bacterial reduction of sulphate has not been proven, and other process, such as inorganic sulphate reduction, could produce that sulphide content [18] (p. 146); but because the latter is very rare, and the most common origin of $\mathrm{S}^{2-}$ is the bacterial reduction of sulphate, we calculated the potential effect of bacterial sulphate reduction on the dissolved sulphate. We do not go into the details of the hypothetical process.

Table 4. The calculated $\delta^{18} \mathrm{O}$ and $\delta^{34} \mathrm{~S}$ values of bisulphate before bacterial reduction in six sulphate samples. The enrichment factors we used in this calculation are $\varepsilon_{34 \mathrm{~S}}=70 \%$ o and $\varepsilon_{18 \mathrm{O}}=20 \%$ o. The $\varepsilon_{34 \mathrm{~S}} / \varepsilon_{18 \mathrm{O}}$ ratio is 3.5 , which is the mean value of the range $2.5-4.5$ defined by Fritz et al. (1989) [29].

\begin{tabular}{|c|c|c|c|c|c|}
\hline Thermal Wells & $\begin{array}{c}\delta^{34} \mathrm{~S}[\% o] \\
\text { Sulphate } \\
\text { (Measured) }\end{array}$ & $\begin{array}{c}\mathcal{\delta}^{18} \mathrm{O}[\% \text { o] } \\
\text { Sulphate } \\
\text { (Measured) }\end{array}$ & $\begin{array}{c}\mathrm{S}^{2-} \\
{[\mathrm{mg} / \mathrm{L}]}\end{array}$ & $\begin{array}{c}\delta^{34} \mathrm{~S}[\% o] \\
\text { Sulphate } \\
\text { (Calculated) }\end{array}$ & $\begin{array}{c}\delta^{18} \mathrm{O}[\% \text { o] } \\
\text { Sulphate } \\
\text { (Calculated) }\end{array}$ \\
\hline Csepel well II (Budapest) & 15.61 & 5.45 & 0.4 & 15.58 & 5.43 \\
\hline Széchenyi well II (Budapest) & 17.18 & 4.91 & 0.2 & 17.16 & 4.90 \\
\hline Széchenyi well I (Budapest) & 17.72 & 5.05 & 0.3 & 17.69 & 5.03 \\
\hline Lukács well IV (Budapest) & 11.63 & 4.22 & 0.98 & 11.50 & 4.14 \\
\hline Lukács well V (Budapest) & 10.28 & 5.18 & 0.64 & 10.16 & 5.11 \\
\hline Strand thermal well (Göd) & 14.01 & 4.94 & 0.34 & 13.95 & 4.90 \\
\hline
\end{tabular}

The bacterial reduction (for example, by Desulfovibrio desulfuricans, which is a natural anaerobic bacterium species) of sulphate removes, preferentially, the light isotopes of oxygen and sulphur from the sulphate in the reservoir and causes isotopic enrichments for both ${ }^{18} \mathrm{O}$ and ${ }^{34} \mathrm{~S}$ in the residual sulphate [29]. The typical values for the ratio of enrichment factors $\varepsilon_{34 S} / \varepsilon_{180}$ ranged from 2.5 to 4.5 [29]. Supposing that the bacterial reduction took place at enrichment factors of $\varepsilon_{34 \mathrm{~S}}=70 \%$ ond $\varepsilon_{18 \mathrm{O}}=20 \%$, we calculated what the $\delta^{18} \mathrm{O}$ and $\delta^{34} S$ values of bisulphate were before the reduction. As we can see from Table 4 , the possible effect of bacterial reduction on the $\delta$ values is insignificant; practically, this effect is in the range of the analytical uncertainty.

\section{Conclusions}

Thermal waters produced by wells and springs from the Buda Thermal Karst Aquifer of Budapest and its surroundings are rich in dissolved sulphate. The origin of this bisulphate has been determined by means of isotope geochemical methods.

Based on the stable sulphur isotopic composition of the dissolved sulphate we can infer that bisulphate in the thermal wells $\left(>30^{\circ} \mathrm{C}\right)$ originates from dissolution of Permian evaporates containing gypsum and anhydrite. These waters are old and were infiltrated during the Ice Age (>11 ka BP) with few exceptions, to which a small amount of cool water mixed, mostly affecting their radiocarbon age. The latter is below $9 \mathrm{ka}\left({ }^{14} \mathrm{C}\right.$ calculated age).

Luke-warm waters $\left(\mathrm{T}=15-30^{\circ} \mathrm{C}\right)$ are probably a mixture of cool and hot karstic water components based on the oxygen isotopic composition of the waters. The bisulphate originates supposedly from the oxidation of pyrite from the Tard and Kiscelli Clay Formations based on the stable sulphur isotopic composition. 
An evaluation of water chemistry of thermal karstic wells suggest that bisulphate is a dissolution product of sulphate minerals; the bicarbonate is a dissolution product of calcite and dolomite; the chloride comes from $\mathrm{NaCl}$; some portion of $\mathrm{Na}$ content comes from cation exchange between clay minerals and water $[\mathrm{Ca} \leftrightarrow(\mathrm{Na}, \mathrm{K})]$.

In the waters of $>60^{\circ} \mathrm{C}$ the bisulphate-water oxygen isotope thermometer gives the same temperature as the outflow temperature, indicating that these waters are undisturbed waters and their temperature was never higher than the present one. In the thermal waters with lower temperatures, the bisulphate-water oxygen isotope thermometer outputs a slightly higher temperature those of the previous ones, indicating that a small amount of cool water could mix with this water. In the thermal waters younger than $9 \mathrm{ka}$, the bisulphate-water oxygen isotope thermometer gives temperatures of over $80{ }^{\circ} \mathrm{C}$, which can be real, but their age and $\delta^{18} \mathrm{O}_{\mathrm{H} 2 \mathrm{O}}$ indicates the mixing of young cool water to old hot water.

Author Contributions: Conceptualization, I.F., J.D. and S.H.; field work, J.D.; isotope analysis, A.P., A.T. and I.F.; data curation, V.R.S., J.D. and I.F.; Writing-Original draft preparation, V.R.S. and I.F.; Writing-Review and editing, A.P., Á.L. and A.T.; visualization, V.R.S.; supervision of sulphate isotope measurements, S.H.; funding acquisition, I.F.

Funding: This research was funded by the Hungarian Scientific Research Fund, grant number K-60921, and the National Research, Development and Innovation Office, grant number SNN118205.

Acknowledgments: The authors would like to thank, for the water oxygen isotope measurements of a set of the samples, Krisztina Kármán.

Conflicts of Interest: The authors declare no conflict of interest. The funders had no role in the design of the study; in the collection, analyses, or interpretation of data; in the writing of the manuscript, or in the decision to publish the results.

\section{References}

1. Szalontai, G. A budapesti hévizek kémiai tulajdonságai (Chemistry of the Budapest Thermal Waters). In Budapest hévizei (Thermal Waters of Budapest); Alföldi, L., Bélteky, L., Böcker, T., Horváth, J., Korim, K., Liebe, P., Rémi, R., Eds.; VITUKI: Budapest, Hungary, 1968; pp. 59-71. (In Hungarian)

2. Lorberer, Á. Budapest hévizei mérnökgeológiai szemmel (Thermal waters of Budapest from the aspect of engineering geology). In Alagút-és mélyépitó szakmai napok, Proceedings of the a Millenium Után, Európával, jövőnk környezetéért, Eger, Hungary, 27-28 May 2002; MTESZ Közlekedéstudományi Egyesület-Deutsche Ingeinurkammer: Budapest, Hungary, 2002; pp. 71-78. (In Hungarian)

3. Alföldi, L. Budapesti hévizek (Thermal waters of Budapest)—VITUKI Közlemények, 20.; VITUKI: Budapest, Hungary, 1979; pp. 1-102. (In Hungarian)

4. Krouse, H.R.; Mayer, B. Sulphur and oxygen isotopes in sulphate. In Environmental Tracers in Subsurface Hydrology; Cook, P.G., Herczeg, A.L., Eds.; Springer: Boston, MA, USA, 2019; pp. 195-231.

5. Apollaro, C.; Dotsika, E.; Marini, L.; Barca, D.; Bloise, A.; De Rosa, R.; Doveri, M.; Lelli, M.; Muto, F. Chemical and isotopic characterization of the thermo mineral water of Terme Sibarite springs (Northern Calabria, Italy). Geochem. J. 2012, 46, 117-129. [CrossRef]

6. Michalik, A.; Migaszewski, Z.M. Stable sulfur and oxygen isotope ratios of the Świętokrzyski National Park spring waters generated by natural and anthropogenic factors (south-central Poland). Appl. Geochem. 2012, 27, 1123-1132. [CrossRef]

7. Migaszewski, Z.; Galuszka, A.; Michalik, A.; Dolegowska, S.; Migaszewski, A.; Halas, S.; Trembaczowski, A. The use of stable sulfur, oxygen and hydrogen isotope ratios as geochemical tracers of sulfates in the podwisniowka acid drainage area (South-Central Poland). Aquat. Geochem. 2013, 19, 261-280. [CrossRef]

8. Porowski, A.; Porowska, D.; Halas, S. Identification of sulfate sources and biogeochemical processes in an aquifer affected by Peatland: Insights from monitoring the isotopic composition of groundwater sulfate in Kampinos National Park, Poland. Water 2019, 11, 1388. [CrossRef]

9. Vendel, M.; Kisházi, P. Összefüggések melegforrások és karszt-vizek között a Dunántúli-középhegységben megfigyelt viszonyok alapján I and II (Correlations between thermal springs and Karstic waters in the Transdanubian Ranges I and II). MTA Müszaki Tudományok Osztályának Közleményei 1964, 32-33, 205-234, 393-417. (In Hungarian) 
10. Mádl-Szőnyi, J.; Erőss, A.; Tóth, Á. Fluid flow systems and hypogene karst of the transdanubian range, Hungary-With special emphasis on buda thermal karst. In Hypogene Karst Regions and Caves of the World; Klimchouk, A., Palmer, A.N., De Waele, J., Auler, A.S., Audra, P., Eds.; Springer: Cham, Switzerland, 2017; pp. 267-278.

11. Vető, I.; Nagymarosy, A.; Brukner-Wein, A.; Hetényi, M.; Sajgó, C. Salinity changes control isotopic composition and preservation of the organic matter: The Oligocene Tard clay, Hungary revisited. In Proceedings the of 19th International Organic Geochemistry, Istanbul, Turkey, 6-10 September 1999; Abstracts Part I, TÜBITAK; Marmara Research Center: Istanbul, Turkey, 1999; pp. 411-412.

12. Hámor, T. Az anoxikus üledékképződés és a korai diagenezis vizsgálata stabil izotóp mérések alkalmazásával (Study of anoxic sedimentation and early diagenesis by means of stable isotopes). In Országos Tudományos Kutatási Alap 259. sz. téma zárójelentése (Final Report of Project no. 259 Financed by the National Scientific Research Fund); Hungarian Geological Institute (Now Mining and Geological Survey of Hungary): Budapest, Hungary, 1991. (In Hungarian)

13. Hámor, T. Stabil izotóp mérések alkalmazása szedimentológiai és környezetvédelmi problémák megoldásában (Application of stable isotope measurement for sedimentological and environmental problems). In Az Országos Tudományos Kutatási Alap F007373. sz. kutatásának zárójelentése ((Final Report of Project no. F007373 Financed by the National Scientific Research Fund); Mining and Geological Survey of Hungary: Budapest, Hungary, 1997. (In Hungarian)

14. Newton, R.J.; Pevitt, E.L.; Wignall, P.B.; Bottrell, S.H. Large shifts in the isotopic composition of seawater sulphate across the Permo-Triassic boundary in northern Italy. Earth Planet. Sci. Lett. 2004, 218, 331-345. [CrossRef]

15. Claypool, G.E.; Holser, W.T.; Kaplan, I.R.; Sakai, H.; Zak, I. The age curves of sulfur and oxygen isotopes in marine sulfate and their mutual interpretation. Chem. Geol. 1980, 28, 199-260. [CrossRef]

16. Cortecci, G.; Reyes, E.; Berti, G.; Casati, P. Sulfur and oxygen isotopes in Italian marine sulfates of Permian and Triassic ages. Chem. Geol. 1981, 34, 65-79. [CrossRef]

17. Clark, I.D.; Fritz, P. Environmental Isotopes in Hydrogeology; Lewis Publishers: Boca Raton, FL, USA, 1997.

18. Dogramaci, S.; McLean, L.; Skrzypek, G. Hydrochemical and stable isotope indicators of pyrite oxidation in carbonate-rich environment; the Hamersley Basin, Western Australia. J. Hydrol. 2017, 545, 288-298. [CrossRef]

19. Drever, J.I. The Geochemistry of Natural Waters. Surface and Groundwater Environments, 3rd ed.; Prentice Hall: Upper Saddle River, NJ, USA, 1997.

20. Fórizs, I.; Czuppon, G.; Kern, Z.; Kohán, B.; Deák, J. Relationship between the isotopic characteristics of local precipitation and groundwater in Hungary. In Book of Abstracts—44th Annual Congress of International Association of Hydrogeologists. "Groundwater Heritage and Sustainability", Proceedings of the International Association of Hydrogeologists (IAH), Dubrovnik, Croatia, 25-29 September 2017; Posavec, K., Marković, T., Eds.; Croatian National Chapter of the International Association of Hydrogeologists: Dubrovnik, Croatia, 2017; p. 258.

21. Deák, J.; Coplen, T.B. Identification of Holocene and Pleistocene groundwaters in Hungary using oxygen and hydrogen isotopic ratios. In Isotopes in Water Resources Management (Symposium Proceedings, Vienna, 1995); International Atomic Energy Agency: Vienna, Austria, 1996; Volume 1, p. 438.

22. Longinelli, A.; Flora, O. Isotopic composition of gypsum samples of Permian and Triassic age from the north-eastern Italian Alps: Paleoenvironmental implications. Chem. Geol. 2007, 245, 275-284. [CrossRef]

23. Kusakabe, M.; Robinson, B.W. Oxygen and sulfur isotope equilibria in the $\mathrm{BaSO}_{4}-\mathrm{HSO}_{4}{ }^{-}-\mathrm{H}_{2} \mathrm{O}$ system from 110 to $350{ }^{\circ} \mathrm{C}$ and applications. Geochim. et Cosmochim. Acta 1977, 41, 1033-1040. [CrossRef]

24. McKenzie, W.F.; Truesdell, A.H. Geothermal reservoir temperatures estimated from the oxygen isotope compositions of dissolved sulfate and water from hot springs and shallow drillholes. Geothermics 1977, 5, 51-61. [CrossRef]

25. Lloyd, R.M. Oxygen isotope behavior in the sulfate-water system. J. Geophys. Res. 1968, 73, 6099-6110. [CrossRef]

26. Mizutani, Y.; Rafter, T.A. Oxygen isotopic composition of sulphates, 3. Oxygen isotopic fractionation in the bisulphate ion-water system. N. Zeal. J. Sci. 1969, 12, 54-59.

27. Mizutani, Y. Isotopic composition and underground temperature of the Otake geothermal water, Kyushu, Japan. Geochem. J. 1972, 6, 67-73. [CrossRef] 
28. Chiba, H.; Sakai, H. Oxygen isotope exchange rate between dissolved sulphate and water at hydrothermal temperatures. Geochim. et Cosmochim. Acta 1985, 49, 993-1000. [CrossRef]

29. Fritz, P.; Basharmal, G.M.; Drimmie, R.J.; Ibsen, J.; Qureshi, R.M. Oxygen isotope exchange between sulphate and water during bacterial reduction of sulphate. Chem. Geol. (Isotope Geosci. Sect.) 1989, 79, 99-105. [CrossRef] 